\title{
The trial of Jesus in the Gospel of Mark
}

\section{E Bammel \\ University of Cambridge}

\begin{abstract}
The gospel of Mark contains summaries, a 'short report' and the long report on the deliberations of the Sanhedrin. The latter consists of four fragments strung together by the redactor and put under the vinculum of the nocturnal session. Each of these passages contains information, the relevance of which is discussed in this paper.
\end{abstract}

\section{INTRODUCTION}

'The most interesting isolated problem which historical jurisprudence can present' such was the characterization formulated by Innes (1899:2). This was nearly a hundred years ago and the statement refers only to the juridical problems. Innes knew nothing of literary criticism, form criticism and the like, which bedevil present day researchers. The problem has become so complex that its solution cannot be attempted in one stroke $^{1}$. It is for this reason that the much more circumscribed subject of the treatment of the trial in Mark's gospel is dealt with in these pages.

One cannot speak of Mark without first mentioning Hans Lietzmann. In his $A k a-$ demierede of 1931 (Lietzmann 1931; 1958:251-25) he gave a critical examination of Mark's account (Lietzmann 1931a, 1931b, 1932, 1958). He pointed to its sandwich structure between passages dealing with Peter, he noticed that the adjuration by the High Priest is not in keeping with the standard Jewish terminology and argued for the unrestricted competence of the Sanhedrin to condemn a person to death and to execute the culprit. He concluded from this that the Markan account of two trials is not a constitutive part of the tradition but belongs to the redactional level and therefore ceases to be of historical importance. Lietzmann did not deny that a meeting of the Sanhedrin had taken place. The historian cannot say more and, regrettably, has to concentrate on the trial before Pilate. Hardly any detailed investigation can have been more influential than these pages ${ }^{2}$ - it radiated even to Vatican II. One cannot fail to be fascinated by the paper even after more than two generations. It was the stroke of a man of genius

* Lecture delivered at the University of the Witwatersrand. 
but at the same time a tour de force. Followers of his, especially Winter (1961), went even further and transferred what was primarily an exercise in literary criticism although observations of Sachkritik were not excluded - to the historical level: there was no Jewish trial properly speaking, only a Roman determination and execution.

It seems that Mark's account of the trial before Caiaphas has ceased to be relevant. It is proposed to reexamine Mark, before we follow Lietzmann, and to concentrate on references to the trial in the main body of this gospel which have not been dealt with by the Berlin scholar.

\section{MARK 8:31, 9:31 AND 10:33-34}

Mark produces a short sketch of the events, which is transmitted not only once but in three versions, versions which are more or less extended but basically identical: Mark 8:31, Mark 9:31 and Mark 10:33-34. These summaries point on the one hand to details of the passion, whereas on the other hand they bring out the meaning of these events. It is the latter which is emphasized and meant to guide the reader to an understanding of the long account. In this respect the summaries give more than the long account. The view is frequently taken that the summaries have been drawn from the long account and therefore cease to be of independent value, as far as they reproduce details of the passion. This is not completely correct. Mark 8:31 places $\pi \circ \lambda \lambda \dot{\alpha}$ $\pi \alpha \theta \varepsilon i \nu$ before the condemnation, which is expressed merely by $\dot{\alpha} \pi \circ \kappa \tau \alpha \nu \theta \hat{\eta} \nu \alpha \iota$ and

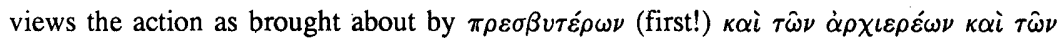
$\gamma \rho \alpha \mu \mu \alpha \tau \varepsilon \omega \nu$. It may thereby point to traditions which are not spelled out in the trial account itself. It is significant that the three formulae quite obviously have a common structure, while they are at variance in detail.

Furthermore, the gospel contains remarks which in their present context form an introduction to the historical or legal aspects of the trial: Mark 14:1-2, Mark 11:18 and Mark 3:6.

The account of the trial has prefixed to it the remark in Mark 14:1-2, which therefore is normally taken as the introduction to the story of the trial. In fact, however, it introduces the narrative of Jesus's anointing (Mark 14:3-9). Mark 14:1a is closely linked to this story and introduces it well, especially if proper account is taken of verse $8^{3}$. Mark 14:2, on the other hand, does not accord easily with the anointing nor does it agree with the long account of the trial. Mark 14:2 gives a proviso and a direction which was not only not followed up but is at odds with what actually happened in the passion story ${ }^{4}$. It cannot have been formulated in conjunction with the framework of the trial account. It must be assumed to have come into existence independently.

The second short account, repeated in a less precise form in Mark 12:125, is placed after the cleansing story and also at the beginning of the controversy stories of

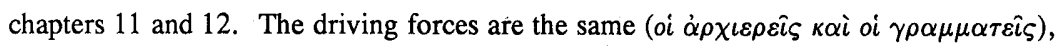




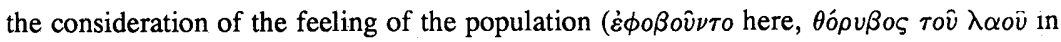
chapter 14) is present as well. The reaction of the people is noticed and based on Jesus's teaching $(\delta\llcorner\delta \alpha \chi \eta)$, whereas it is expressed in tentative terms in Mark 14:2 ( $\mu \dot{\eta} \pi o \tau \varepsilon \kappa \tau \lambda$.), quite apart from the fact that $\dot{\varepsilon} \xi \varepsilon \pi \lambda \dot{\eta} \sigma \sigma \varepsilon \tau o$ is far less strong a word than $\dot{\varepsilon} \phi o \beta o v v y \tau$. Instead, fear of Jesus himself is indicated. The intention is the same, although the result aimed at is expressed less precisely ( $\dot{\alpha} \pi 0 \lambda \varepsilon \dot{\varepsilon} \sigma \omega \sigma \nu)$ than in Mark 14:1 ( $\kappa \rho \alpha \tau \dot{\eta} \sigma \alpha \nu \tau \varepsilon \varsigma \dot{\alpha} \pi \sigma \kappa \tau \varepsilon i \nu \omega \sigma \iota \nu)$. The tactical device of Mark 14:2a and Mark 14:1b ( $\dot{\varepsilon} \nu$ $\delta \delta^{\lambda}(\omega)^{6}$ is absent completely. The formulation is less precise, but obviously related to Mark 14:1 and the following verses. The sentence is appended by a qualification which is meant to explain the delay in executing what was their desire. The attitude taken by the people is expressed in words reminiscent of Mark 1:22 (see also Mk 6:2; $7: 17 ; 10: 26$ ). This repetition is a Markan feature. Mark $11: 18 \mathrm{a}$ and $18 \mathrm{~b}$ is a skeleton formulation linked with other elements.

It has its place within or rather at the end of the cleansing story and is linked with it by $\ddot{\eta} \kappa o v \sigma \alpha \nu$ which refers to Jesus's action. The cleansing is thus viewed as an event that makes the implementation imperative. It is not the main reason for the attitude taken by the high priests and scribes but serves as an additional point. One would, however, expect details of the reaction of the forces opposing Jesus, if that connection were genuine. It is rather an artificial setting that is given to the formulation of Mark 14:18. Nor does it agree easily with what follows. The high priests and scribes, accompanied by the elders, make their appearance again in Mark 11:27. There, however, they do ask a question; it is a question which is indicative for the beginning of an open ended deliberation.

Surprisingly similar is Mark 3:6, a sentence which is given its location at the beginning of the ministry of Jesus. The action is brought about by two groups. Their

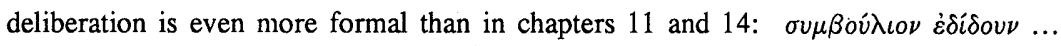

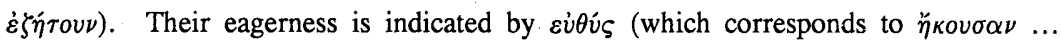
$\left.\dot{\varepsilon} \zeta \eta^{\prime} \tau o v \nu\right)$. The structural elements are the same apart from the fact that the reflection about the people is completely absent. One detail is remarkable: the enemies are called $\Phi \alpha \rho \iota \sigma \alpha \hat{i} o \iota \quad \mu \varepsilon \tau \grave{\alpha} \tau \hat{\omega} \nu$ 'H $\rho \omega \delta \iota \alpha \nu \hat{\omega} \nu$, a formulation which is almost unique. The connection with the context is described by $\dot{\varepsilon} \xi \varepsilon \lambda \theta \sigma o v \varepsilon \varsigma$, a surprising word as the ' $\mathrm{H} \rho \omega \delta \iota \alpha \nu$ oi had not been mentioned in the previous story or in the set of stories which is concluded by this verse.

There is no doubt that the set of five ${ }^{7}$ controversy stories (Mark 2:1-3:6) which is pointedly introduced by the elaborate account of a miracle $(\mathrm{Mk} 1: 40-45)^{8}$, is an entity of its own (Baldensperger 1881:181). It was composed without consideration of the sequence of the Markan narration (Weiss 1903:153-161). It is more sophisticated than the account in chapters 1:1-39, and may have an origin of its own. 
It has been maintained that there is no development or only in the exterior form of the unit: the healing of the paralytic and the subsequent intimation of blasphemy ${ }^{9}$ is the most far-reaching encounter and the last case 'verhältnismäßig der leichteste' (Weiss 1903:154). This may possibly be correct from a theological point of view but the narrator is at pains to describe the juridical situation. It was Stauffer who noticed the character of this context and recognized the persons alluded to in Mark 3:6 as witnesses put up as a trap (Hinterhaltszeugen) and the forgiving of sins as an usurpation of a divine prerogative and therefore blasphemy, which was quickly pointed to by those present. What was the climax from the point of view of literary presentation according to Weiss became the actual turning point in the opinion of Stauffer (1959:165).

The redactor ${ }^{10}$ of these six stories used them in order to give an overall picture of the ministry of Jesus, to mark out his specific status and to select characteristic encounters with the Jews which guide the reader to trial and execution. They indicate a development of events and show that the outcome was inevitable.

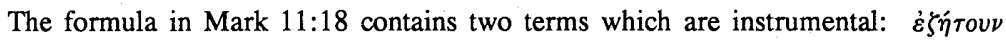
and $\dot{\alpha} \pi 0 \lambda \hat{\varepsilon} \sigma \omega \sigma \iota \nu$. The latter occurs in Mark 3:6 as well, whereas the former is expressed more precisely there. They are linked in Mark $11: 18$ by $\pi \hat{\omega} \varsigma$, which presupposes a decision properly speaking as having taken place already (and thereby agrees with the second term in Mark 3:6). Subjects are the $\alpha \rho \chi \iota \varepsilon \rho \varepsilon \hat{\iota} \varsigma \alpha \alpha i \gamma \rho \alpha \mu \mu \alpha \tau \varepsilon i \varsigma$ and not the $\left.\Phi \alpha \rho \iota \sigma \alpha \hat{\imath} \iota \iota \mu \varepsilon \tau \grave{\alpha} \tau \hat{\omega} \nu{ }^{\prime} \mathrm{H} \rho \varphi \delta \iota \alpha \nu \hat{\omega} \nu\right)$. The sentence is appended by a qualification which is meant to explain the delay in executing what was their desire. The attitude taken by the people is expressed in words reminiscent of Mark 1:22 (cf also Mk 6:2; 7:17; $10: 26)$. This repetition is a Markan feature. Mark 11:18a and $b$ is a skeleton formulation linked with other elements. Not far from Mark 11:18, the Pharisees and Hero-

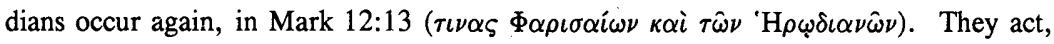
however, as agents of the $\dot{\alpha} \rho \chi \iota \varepsilon \rho \varepsilon i \varsigma$ $\kappa \alpha i \quad \gamma \rho \alpha \mu \mu \alpha \tau \varepsilon i \varsigma$, who commissioned ( $\dot{\alpha} \pi o^{-}$

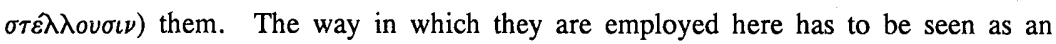
attempt to reconcile two different approaches ${ }^{11}$. The result is that the second set of

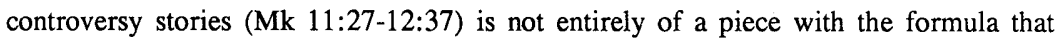
gives the heading.

The formula in Mark 14:1-2 does not indicate any reason for the attitude taken by the Jewish authorities. It is just taken for granted that they have satisfied themselves and the verse considers only the way in which to bring the case to the desired conclusion. Still, the connection with the cleansing, established by Mark 11:18, cannot have been forgotten by the redactor. We must assume that he at least saw the deliberation in this very light. 
Nor does the formula in Mark 14:ff contain information about the time of the council. It states, however, quite clearly that the evidence was such that a decision could be taken on how to destroy Jesus - this may point to a situation after the decision itself had been taken. The additional element in Mark 14:2 ( $\mu \grave{\eta} \dot{\varepsilon} \nu \kappa \tau \lambda$.) points to a time and situation which is not the actual date of the execution of Jesus. This, at first sight at least, is not the impression to be gained from Mark 14:52-ff. It is there that the case appears to be more or less open, that evidence has to be brought forward and a decision is about to be taken at this occasion. The sentence cannot have been formulated in conjunction with the framework of the account of the trial. It must be assumed to have come into existence independently.

What holds the three statements together is the impression they convey about the status quaestionis. Mark 3:6 mentions a decision which was taken, Mark 11:18 deals with the question of the proper way of implementing a verdict, the pronouncement of which is presupposed, and Mark 14:1-2, obviously closely linked with Mark 11:18, with the same. Formulae 2 and 3 presuppose a time-lag between the condemnation and its implementation. This is not easily reconcilable with the long account (Daube 1973).

It does, however, agree with certain data of the Gospel. Mark 3:6 is preceded by references that describe the building up of tension. Some of them have a juridical ring. Mark 2:15 renders a question directed to the disciples about the behavior of Jesus towards unclean people, obviously in order to warn his pupils against following this example. Mark 2:23 reports a warning directed against Jesus himself, because his disciples, those for whom he had taken responsibility, had violated the Sabbath law. Mark 3:2 refers to those who were prepared to act as witnesses against Jesus as soon as the occasion arises ${ }^{12}$. Apart from this a case of lying in wait (Mk 2:6; cf Stauffer $1959 ; 19: 103)$ and of grave offense (Mk 2:7) taken by the scribes is mentioned at the beginning of the set of stories - the narration was reworked (Dibelius 1933:263) and is coloured by the desire of the Christian community to find evidence for the pardoning of sins by Jesus. An earlier form may have contained a Sabbath healing of the kind recorded in John 5 and 9. It is the intention of the collector of the stories to picture Jesus as surrounded by adversaries eager to proceed to action against him. The same tendency is to be found in the second set of controversy stories: Mark 12:13 employs the word $\dot{\alpha} \gamma \rho \varepsilon \dot{v} \omega$ to give expression to $i^{13}$.

The questions dealt with in the first set of these stories concentrate on the Sabbath law. A transgression of it-did indeed carry the death penalty. Was it, however, enforceable vis à vis the Roman authorities? Would they be likely to endorse a death penalty for such a crime and give their fiat? The uncertainty about this may have made the Jews move towards the administration of lynch law. 
The context of the second and third formulae points, although it is less markedly brought out, in the direction of a crime connected with the cleansing of the temple.

In conclusion: the three formulations sit more or less lightly in their present contexts, whereas they are structurally interrelated. They are likely to be variations of the same formula, variations that resulted in interesting additions but also omissions of detail. They are given their present place in the gospel at cross-roads in Jesus's ministry in order to bring out the relevance of certain events. Although they themselves lack any indication about the reason for the measure taken by the Jewish authorities, the formulae are placed in a context which links the proceedings against Jesus with different gravamina: the attitude vis à vis the Sabbath on the one hand, the Temple on the other. The former seems to have receded in importance at the moment of the final confrontation, when the matter was brought to a climax in Jerusalem, the latter not.

\section{THE TRIAL NARRATIVE IN MARK}

The account contains a number of terms which have a legal meaning and which are indicative for the functioning of the judicial process. They require a preliminary study.

Jewish criminal law is entirely based on the institution of witnesses (Cohn 1972; Finkelstein 1962:182ff; Saalschütz 1853; cf also Mendelsohn 1968). While both parties are heard in questions of arbitration (cf Lk 18:1ff; $\chi \dot{\eta} \rho \alpha-\dot{\alpha} \nu \tau i \delta \iota \kappa о \varsigma)$, it is different in penal law. The proof is based on the statements of the witnesses. They act as accusers, at the same time as those who produce evidence, and, most importantly, as executioners: they raise the first stones against a person who is found guilty owing to their testimony (Sanh 45b). The $\kappa \alpha \tau \dot{\alpha}$-formulation in Mark 14:56-57 is therefore entirely appropriate ${ }^{14}$. The questioning of witnesses and the re-examination of the truth of their statements was therefore of cardinal importance. The story of Susannah and the elders is illustrative for this. It was because some fault was found in the testimony of the elders that a re-examination took place that led, eventually, to her release. In fact, it was their separate interrogation, an innovation in the technique of crossquestioning the witnesses, which is recommended by the story ${ }^{15}$. Older practices, more or less at variance with this ${ }^{16}$, may have survived in cultic matters. A statement of the accused was not required, the admission of his guilt was only expected after the verdict had been passed (Sanh Vi.I; Tos Sanh IX.5). His confession was irrelevant for the outcome of the trial (Innes 1899:56). A case is referred to in Tanchuma, where it so happens that the accused makes what is called a slip of the tongue and the judge condemns him out of his own mouth (Shelach IV.96; cp Lieberman 1944/5) ${ }^{17}$. The judge is the king, the procedure that of a gentile court. 
The number of witnesses laid down in Deuteronomium 17:6 and Sanh VII.5 is 'two or three ${ }^{18}$ ' - a formulation which opens up a hornets' nest of questions. The requirement is said to have been complied with here: $\tau \iota \nu \varepsilon \varsigma$ (verse 57), whereas Matthew reduces to the bare minimum that could be accepted: $\delta$ vio (verse 60) ${ }^{19}$. It is different in Roman law, where the judges are given a more active role. One witness may be considered sufficient and the statement of the accused is regularly taken into consideration.

The case is bound to collapse if the witnesses are found to disagree with each other. It is not the case that the confession of the accused can make up for deficiencies in the testimony produced by the witnesses ${ }^{20}$. To give the accused a hearing is extraordinary, although not unheard of. It so happened in the case of Jeremiah (see chapter 26:12ff) ${ }^{21}$. Sanh V.4 mentions a statement made by the accused: it is to be taken into consideration if it is relevant (ממש:); the court is under no compulsion to do so. The choice of the formulation makes it clear that the proviso is of an extraordinary character. The sentence seems to be an appendix, which displays the tendency to give the picture of an ideal juridical system and may also indicate a tribute paid to Roman law. Maimonides and Bertinoro cling to the view that an opinion given by the accused is irrelevant.

Here it is not an outburst of the accused that is narrated but a statement that is elicited by the president of the court. Such a statement may be provoked for two reasons: in order to give the accused a chance to sway the opinion of the judges or in order to incriminate him by his own words. The former is indicated on the redactionary level of the text of Matthew ${ }^{22}$, the latter on that of Mark $^{23}$. The former may be admissible, the latter probably not.

The questioning carried out by the high priest is an unusual act. Did he 'save the situation', as it is normally taken? Such an impression car only be formed if the account of the trial is of a piece. If that is not the case, it rather points in a different direction. The extraordinary action gives the accused a chance to sway the opinion of the court in his favour. It is a concession, not a threat or intimidation.

This means that the question of the high priest can only be understood under the assumption that a state of affairs existed which differs from the one described in verses 56-59: the matter was more or less settled in Jesus's disfavour, while the reader of verses 56-59 expects Jesus's release.

The questioning is therefore something that is additional to the usual procedure. It finds its consecutio in verse 65 , the so-called buffeting. The description of the scene has undergone some deterioration and amalgamation with the mocking carried out by

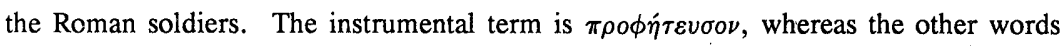


describe an action of bracchial ignomy. Jesus is put under severe pressure to prophesy and this demand is supported by some force carried out by $\tau \imath \nu \varepsilon \varsigma$, members or agents of the court. The call to prophesy receives its meaning if compliance with the request might possibly alter the situation. The proof given for a prophetic status might indeed be a point requiring reconsideration of the matter. The status quaestionis indicated by both the questioning and the call to prophesy is that of a final phase of the proceedings.

Blaspheming is coined as a crime in Numeri 15:30ff and Leviticus 24:11ff. It is defined as a curse of the one whose name had been clearly pronounced (Billerbeck I.1016f.). It is evident that this definition excludes its application to the case of Jesus. It might be different if 'blasphemy' is based on Exodus 22:27 and refers (as it is assumed by the older exegesis; Billerbeck I.1009f) to the judges: Mark 14:62

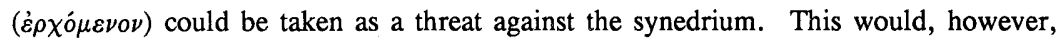
hardly carry the death penalty. And it is only the younger interpretation of Exodus 22:27 which links the verse with the concept of blasphemy.

A statement against the temple would be a very serious matter if it could be proved that it was directed against God himself, who tabernacles in the holy of holies of this building. The announcement, backed by Old Testament examples (Micah, Jeremiah), that God will withdraw from the Temple, was however, not taken to be a capital crime, as the sense of Jesus ben Ananiah shows. It may be different in Roman law. There, the Roman administrator could proceed easily by way of coercitio against threats against a temple and was likely to do so in order to maintain the peace. It is, however, significant that this point does not play any role in Jesus's appearance before Pilate.

The saying attributed to Jesus consists of two parts, the announcement of a new place of worship not made by the hands of men and the forecast of the destruction of the present Temple 24 . The latter, transmitted in different forms, receives its focus if interpreted together with the mountain moving saying (Mk 11:22ff). The tradition gives it its place in Jerusalem. The ópos oirros is therefore the Temple mountain, the splendour of which is nothing compared with real faith in God. This was meant as a stern critique of the sacrificial system and could lend itself to being interpreted as a threat. The versions of the Temple saying transmitted in the New Testament are developments of this basic saying. Would this have been sufficient reason for a death penalty? The case of the other Jesus, known from Josephus (Bell VI§ 301f), who pronounced his cries of doom over Jerusalem for as long as three years and who was only scourged, does not render support to such a view. Modern attempts, although backed by the authority of Wellhausen (109:99; cf also Kilpatrick 1953), to view this accusation as decisive, are not convincing. Had the verses originally functioned in a context now lost? 
The silence of the accused is not unheard of. On the contrary, it is quite normal in proceedings carried out according to the Jewish system. Naboth's reaction to the accusation is not recorded (I Kgs 22) - either he had remained silent or his intervention was not found worth recording. Susannah's reaction does not play any role in the account of her case. In fact, she does not even open her mouth before she is condemned $^{25}$. She does do so in order to protest her innocence and to recommend herself to the Divine grace (Theodotion 42f) ${ }^{26}$. It is different in Roman law. The accused person is given a hearing and expected to speak for himself. His silence is likely to count against him. It may be taken as an admission of his guilt (PsAscon in Act II.5; Quintilian, Jnst III.6.14; cf Paulus 1985:442). Josephus, paraphrasing Genesis 40, narrates that, when incarcerated, Joseph remained silent $(\sigma \iota \gamma \hat{\omega} \nu)$ and did not press for the opportunity to make his defence ( $\left.\dot{\alpha} \pi \sigma_{\lambda o \gamma} \alpha\right)$ ) or to lay open the exact circumstances $(\dot{\alpha} \kappa \rho \iota \beta \hat{\eta})$ of the encounter with Potiphar's wife (Ant§ II.60). He thereby points to opportunities in Hellenistic law, but, what is more important, he wants to convey the impression that he behaved like a Stoic sage ${ }^{27}$ or even like Jesus ${ }^{28}$. He also says that

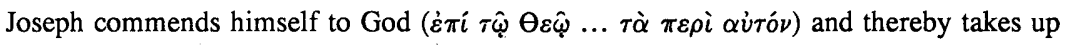
a genuinely Old Testament theme: the suffering servant does not open his mouth (Is 53:7) nor does the Psalmist in his vicissitudes (Ps 38:14ff; 39:10). Although not devoid of a legal meaning the expressions are to be taken as raising the meaning of the gestus to a different level. Silence may be 'beredtes Schweigen' or, as Justin put it,

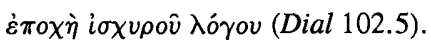

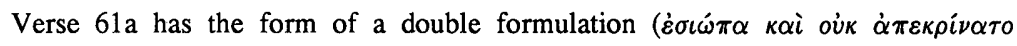
$o \dot{\delta} \delta \varepsilon)$. The parataxis of synonymous verbs is not unknown in the Greek language (Reiser 1984:136). Its occurrence in so compressed a text can, however, not be explained by the preference for ornamentation. It is likely to express something specific. While the second term is taken up in the scene before Pilate (Mk 15:5; also already in Mk 14:60) and therefore to be interpreted as the refusal of the accused to interact with the members of the bench or the presiding judge, it is the first which is likely to convey something specific and calls for an additional interpretation. Asc Is 5.4, where the prophet converses with the spirit while being executed, may assist the interpretation: Jesus, it may tentatively be suggested, is so much occupied with his encounter with God that he has not time to confront anyone else.

The silence was interpreted subsequently. The different statements attributed to Jesus have to be viewed as attempts to interpret this silence. $\Sigma \dot{v}$ ei $\pi \alpha \varsigma$ is not an affirmation as has been pointed out at length by Merx (1902:382ff), but a refusal to return an answer. 
The 'buffeting' of a person standing in the dock is a common practice in order to make him cooperate and to extract a confession from him. The treatment may have been less usual in a Jewish clime, because the confession plays only a minor role. It may be different in the case of a claimant, whose aspirations are checked in this way. He may have been requested to prophesy in conjunction with beatings in order 'ihm das Prophezeien auszutreiben' (Wellhausen 1909:125) or rather to bring about the prophetical activity the seer is reluctant to communicate. There is an enigmatic passage in a tannaitic tradition in Sanh $89 \mathrm{~b}$ on a discussion whether such a reluctant prophet should be flogged 29 . A subtle situation would exist if Mark 14:65 has an apotropaic meaning: the spitting causes uncleanness which impedes the accused to come out with the proof of his prophetical caliber, which he is requested to give at the same time.

In conclusion, the terms that carry a judicial meaning could have functioned in different ways in a trial before the Sanhedrin. Fundamental is the notion of witnesses, while they are absent from the Roman part of it. The interrogation of the accused is quite unusual but not unheard of. His statement hardly satisfies the requirements for blasphemy. This part of the scene is, historical or not, not a constitutive part of the trial. The 'buffeting', on the other hand, may contain elements which are not irrelevant for the historical reconstruction of the trial.

The story of the suffering and death of Jesus is likely to have been narrated and meditated upon (Bertram 1922; Trocmé 1983) at a very early stage. Influences of very different kinds will have exercised their influence on Mark's account. The extraordinary number of variants in the text only echoes what had happened at a much earlier stage.

The account of the trial before the Sanhedrin is normally taken as being of a piece, either an integral part of the whole passion story (Blinzler 1969:58) or a block of material inserted, 'sandwiched' in the account of Peter's denial (Lietzmann 1931a:254). That is, however, not necessarily the case. Mark 14:53 describes the composition of the court: $\dot{\alpha} \rho \chi\llcorner\varepsilon \rho \varepsilon \hat{\imath} \varsigma, \pi \rho \varepsilon \sigma \beta \dot{\tau} \tau \varepsilon \rho o \iota, \gamma \rho \alpha \mu \mu \alpha \tau \varepsilon i \varsigma$. Mark 15:1 repeats: oi $\dot{\alpha} \rho \chi\llcorner\varepsilon \rho \varepsilon \hat{\imath} \varsigma$

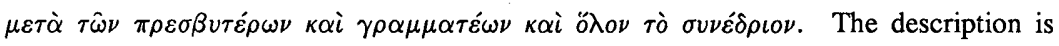

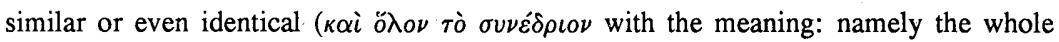
Synedrion). Why, however, is it repeated? What would be the functioning of the repetition? Is it taken over from a different source? Verse 53b and 55a constitute on the one hand an unnecessary repetition, while on the other hand the formulations used to describe the judicial body are different from each other. Verses 56a and 57 speak of a $\psi \varepsilon v \delta o \mu \alpha \rho \tau v \rho i \alpha^{30}$, verses $56 \mathrm{~b}$ and 59 of $\mu \alpha \rho \tau v \rho i \alpha$ which did not agree with each other. Verse 55 mentions an attempt of an official nature, while verse 56 refers to $\pi 0 \lambda \lambda o i$ and 57 names $\tau i v \varepsilon \varsigma$ (see esp verse 65) as those who turned against Jesus. 
$\Pi \alpha \dot{\alpha} \iota \nu$ (verse 61b), especially if it is placed at the beginning of a sentence, tends to be used in order to indicate the beginning of a new source (Knox 1953:1931). The state of affairs - cracks do emerge - calls for further inquiry.

The first part (verse 55f) is in fact a Sammelbericht which indicates the composition of the court in words that differ from verses 53 (Thiel 1938:192), describes the intention or rather states that their action was directed by a hostile bias ( $\dot{\varepsilon} \zeta$ 'ं

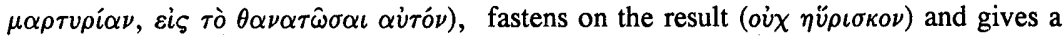
reason for this: although witnesses were produced, their witness did not turn out to be detrimental for Jesus; the testimonies did not coincide with each other and their claims did not stand up to the procedural requirements. The action was futile. On the other hand, the compiler of the Sammelbericht knows that Jesus was executed. What, then, had to follow in order to achieve this result?

Verse 57 could be linked with the preceding verses: $\tau \iota \nu \varepsilon \varsigma$ might be taken as some of the $\pi \circ \lambda \lambda o i$ who had already given witness. Still, the combination is artificial, as the conclusion of the proceedings had been indicated at the end of verse 56 . Verse 57 is an alternative account rather than part of the scene of verse $55 \mathrm{f}$, subsequently spelled out in detail. Nor does it go easily with verse 60ff. Verse 59 forms an interruption. There would be an obvious progression from verse 58 to 60 . Have the verses to be taken as a separate unit? Is the linkage with verse 50 established by oủ $\delta \varepsilon$ oü $\tau \omega \varsigma$ (instead of $o \dot{u}$ ) to be taken as a mark of a secondary hand (Thiel 1938:97)? The situation is in fact different from that depicted in verse 55. The witnesses are in the forefront, they stand up ( $\dot{\alpha} \nu \alpha \sigma \tau \dot{\alpha} \nu \tau \varepsilon \varsigma)$, while the high priests et cetera are additional figures. The high priests of verse 55 , on the other hand, were pictured as having initiated the action. The former is in keeping with the Jewish law of procedure, whereas the latter (verse 55) gives a rather unfriendly interpretation and may reflect an imprecise knowledge of the law that was valid at that time and in these climes. Do the verses function as the constitutional element in the trial scene (Wellhausen 1909:125; Kilpatrick 1953:9; Schweizer 1967:187f; Lührmann 1987) or are they an addition (Hirsch 1940:163)? If the former was the case, the relevance was neutralized by verse 59 and the addition of a second scene (verse 60ff), in which no reference is made to the former.

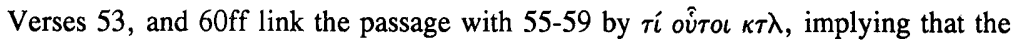
accusation put forward in these verses is still valid. This goes, however, against the meaning of verses 56 and 59 and is therefore to be taken as a secondary realignment. It is not an interrogation with a specific question, which is carried out by the high priest but rather a personal statement expected to be given by Jesus which is implied by the question. It may be that it is only his second question which is reproduced in this frag- 
ment. In any case, the accused does not comply. This is made abundantly clear by the

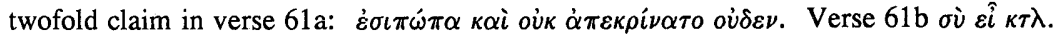
makes explicit what is implied in verse 60 ( $\tau i \ldots \sigma o v)$ : a personal statement. It is surprising that the accused is now described as forthcoming and that in so doing he not only satisfies the curiosity of the inquisitor but says much more than he had been asked to do. This adds weight to the observation based on $\pi \dot{\alpha} \lambda \iota \nu$. In fact, the confession with its abundance of christological titles owes its incorporation in the account to the eagerness of the community to produce a statement as solemn as possible at the most crucial hour of the life of the saviour. Its characterization as blasphemy is only a reflex of this.

It must be concluded: two fundamentally different accounts of the same event are given in verses $50,61 \mathrm{a}$ and $61 \mathrm{~b}$ bff. It was rightly stated: ' $61 \mathrm{~b}-64$ haben ein Schicksal' (Hirsch 1940:136). Verses 63 and 64 belong to the directly preceding verses and not to verse $58^{32}$. Still, verse 64 with its statement of condemnation ${ }^{33}$ is surprising, as verse 62 hardly has a legal bearing. The proper reason for the condemnation is not given in these verses.

The word $\pi \dot{\alpha} \lambda \iota \nu$ in verse $61 \mathrm{~b}$ introduces an alternative version which reaches until verse 64 . Verse $65 \mathrm{f}$, on the other hand, is the sequel to verse $61 \mathrm{a}$. It reports the reaction to Jesus's silence and has its confirmation in 15:1f, the handing over of Jesus to Pilate. The main thrust of the sentence is the move from Jewish to Roman custody. A decision is mentioned in the form of a participle of a verb, the employment of which is strange (Pesch 1977:456) and the meaning of which is completed, 'fertiggestellt, ausgefertigt' (Wellhausen 1909:127).

In conclusion, the account of the hearing before the Sanhedrin consists of four distinct parts: verse 55f, verses 57-59, verses $60-61 \mathrm{a} ; 65 ; 15: 1-2$; and verses $61 \mathrm{~b}-64$. Mark, who is in the habit of combining his sources, reproduced what was available to him.

The judicial situation indicated or presupposed in these fragments is not the same.

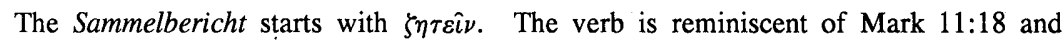
$14: 1$, whereas the $\pi \hat{\omega} \varsigma$, which indicates the particular state of the persecution in both places, is absent here. The juridical dimension $(\mu \alpha \rho \tau \nu \rho i \alpha \nu \ldots$ ovं $\eta \ddot{v} \rho \iota \sigma \kappa o \nu)$ is a new element: a trial is initiated, but it does not come to fruition. Verse 56 belongs to it as an appendix. It may be that the verse was added by the redactor (Hirsch 1940:263) in order to explain the failure (and to heap blame on those concerned).

Verses 57-58 represent faithfully the situation in a Jewish law court. While both

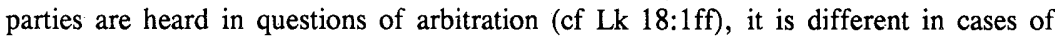
criminal law. The proof was entirely based on the testimony of witnesses. The questioning of the witnesses, the examination of the truth of their statements was therefore of cardinal importance. 
Fragments 3 and 4 look very dissimilar. There are, however, features which are not so far apart. Both verses $61 \mathrm{~b}, 60$ and 65 are attempts to cause Jesus to make a statement. Both verses 64 and 15:1-2 render a decision of the court and put it in words

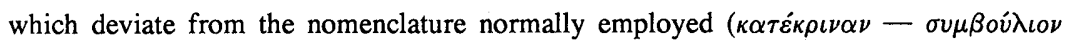
$\dot{\varepsilon} \tau o u \mu \alpha \dot{\alpha} \alpha \nu \tau \varepsilon \varsigma$ ). The fragments could be taken as supplementing each other. Fragment 4 seems to be a developed form of fragment 3 . It replaces the enigmatic silence of Jesus, which must have been a cause of great embarrassment for the community by an emphatic statement of a kind which in the opinion of the Christians was at the heart of Jesus's self-consciousness. Both fragments start with an interrogation of Jesus, they presuppose judicial proceedings which have advanced far and the data of which are viewed as confirmed by the scene itself as is stated at the end (verses 64 and Mk 15:1).

Fragment 3 contains a hearing given to Jesus, that is a concession, the so-called buffeting and the decision to hand him over to Pilate. It does not mention a condemnation expressis verbis. It is, however, based on something like this. The stepping forward of the high priest cannot be the beginning. It indicates an advanced stage of the trial. The handing over presupposes a proper decision. The data of the fragment, which are enigmatic at first sight, make sense if they are seen as a scene that takes place after the condemnation.

Fragment 4 certainly has the form of a trial scene. Witnesses, necessary or not, are referred to, a bench of judges is present, a $\kappa \alpha \tau \dot{\alpha} \kappa \rho \iota \mu \alpha$ is taking place and a reason for it is produced.

Verse 62 , the central statement, however, has a judicial meaning only in a general sense: the one who is to be executed will be received by God and those who take part in the act of condemnation will be confounded $(\% \psi \varepsilon \sigma \theta \varepsilon)$. It does not supply additional information relevant to the state of the affair. It may even have its proper setting after the adverse pronouncement. K $\alpha \tau \varepsilon$ É $\rho \nu \alpha \nu$, which sums up the scene, may have a less precise meaning than it appears - it may mean aburteilen rather than verurteilen ${ }^{34}$.

On the other hand, Jesus's statement is of the greatest importance for the community, its belief and christology. It came to be expanded for this reason - the textual variants give ample evidence for the process. The view that it lacks 'jede Beziehung auf den Prozeß oder die Richter' (Bertram 1922:58) is not mistaken.

The fragment gives evidence for a development in the process of which it was removed from the juridical level and was turned into a key passage for the Christian witness to the Jews. 


\section{CONCLUSION}

The views on the trial conveyed in these fragments are not of a piece. Fragment 1 gives a summary of the events, speaks of abortive attempts made by the court and the accusing witnesses, which would have resulted in Jesus' release. This, it is presupposed, did not happen. This means, the Sammelbericht requires a second action of some kind, which is not transmitted. Fragment 2 focuses on the central point of the accusation and gives details of the testimonies, which however, break down. In its overall view it is identical with fragment 1 . Fragments 3 and 4 supply a sequel, the existence of which is implied by fragment 1 . Whether their contents agree with what is envisaged in fragment 1 , cannot be said with certainty.

The comparison between the fragments leads to giving special consideration to fragments 2 and 3. Fragment 2 contains a definite judicial statement which is at odds with the actual outcome of the trial. It is therefore likely to contain some reliable information. Its setting in the nocturnal scene is loose, it may have been transferred from an earlier occasion. Verse $60 \mathrm{c}$ ( $\tau i$ oüto $\kappa \tau \lambda$.) which establishes a link between 2 and 3 may be patchwork of the redactor. Fragment 3 refers to a scene after the condemnation, fragment 4 describes a scene aimed at finding a reason for a condemnation - this is achieved although the evidence extracted from Jesus is unsatisfactory for this purpose.

How far can they constitute a contribution to the historical question? Fragments 1 and 2 refer to stages which cannot easily be put into the framework of one session. It is fragment 4 which agrees with the framework of the nocturnal session. Fragment 3 points strongly in the direction of preceding events and gives the picture of almost abortive attempts against the life of Jesus. Fragment 2 may fit into the framework. The possibility can, however, not be ruled out that it was imported and had its original place at some other occasion, not necessarily in the presence of Jesus.

There is a decisive difference between the long and short accounts. The former takes the case as something that is still an open question. It is only on the following day that a state of affairs is reached which corresponds to Mark 3:6: $\sigma \nu \mu \beta o u ́ \lambda \iota \nu \nu$ $\pi o \iota$ б $\sigma \nu \tau \varepsilon \varsigma$. Does this date and time, however, coincide with the short account? The third version of it gives a proviso which excludes Passover and says nothing about the time of the decision. The second is not at variance with the third, whereas the first version provides no date at all.

The redactor Mark's own contribution to the picture consists in the placing together of the different traditions he was able to get hold of. In doing this he put them under one heading, the nocturnal session. It may be that the time and location had figured already in one of the sources, but it was he who pressed the data into.this schema. 
The reader vas meant to form the impression that all the decisive actions took place during this night. He may have added certain tinges of colour, in order to achieve this result. It is likely that verse $60 \mathrm{c}$ ( $\tau$ i oürou ...), which looks back to something different to the statement given by the witnesses in fragment 2 , serves as a link and is, wholly or in part, due to the evangelist. Likewise the frequency of the $\kappa \alpha \tau \alpha$-formulation is suspect. The $\pi \rho \omega i$ at the beginning of Mark 15:1 may equally be a marker added by Mark. Whether the colourful $\dot{\alpha} \nu \alpha \sigma \tau \dot{\alpha} \varsigma$ in Mark 14:60 (and already in verse 57) was added by him as well, may remain undecided. More important: the forging together could not be executed without reducing the material available. The hiatus between 61a and $61 \mathrm{~b}$ has already been mentioned. More of this kind is likely to have happened. The pieces 2-4 are fragments patched together. The beginnings were omitted in each case. Finally, the evangelists, keen to move on to the theological implications of the trial, reported only the minimum of the events and neglected the juridical side of them to a large extent. Already Mark is affected by this tendency, although it must be added that some of the juridical data are still recognizable in his account, while they tend to retreat in the parallel narratives ${ }^{35}$.

The scrutiny of the traditions themselves yields certain data which may be relevant for the historical reconstruction: Mark's view of events as having taken place in less than 24 hours is something like an iron fetter which compresses events which took place over a longer period, as, indeed, the whole concept of a passion week is artificial (and unknown to the Lukan tradition) ${ }^{36}$. Mark 14 is an amalgamation of two points of view, one according to which the nocturnal hearing in front of the culprit is meant to be the verification of points of accusation which had been found convincing some time before, and another according to which the matter was still in the balance and the accusation almost at the point of collapse. The historical relevance of the Markan material can only be evaluated in comparison with what emerges from other sources. We possess, it is agreed, three pillars of tradition: Luke, John and the Jewish sources, apart from some secondary material. It was the intention of this paper to add to this the second gospel, a document which had been found elusive by present-day researchers. To project the material of the different sources to the historical level and to distill it is another task.

\section{END NOTES}

1 Even Brown (1994) is still affected by this inclination in research.

2 For the appreciation of his thesis, see the items listed by Blinzler (1969:35). Lohmeyer $(1937: 329,331)$ argues that Mark 14:2 may have been formulated with the intention 'das Synedrium von der Schuld am Tode Jesu zu entlasten und sie allein einem Jünger und der römischen Behörde zuzuschieben' (Lohmeyer 1937:291). This is quite a far-reaching consequence! 
3 It gives a hint to the death of Jesus and a burial without any honorific actions, that is, to an event which is toto coelo different from the impression the gospels try to convey but which may surface in extracanonical tradition (see e g Bakhuizen van den Brink 1927:213). It may be noted that Weiss held the view that the anointing story is the end of $Q$ and is given this position by the author in lieu of an account of the passion story (see Stählin 1970:39). For the interpretation of Mark 14:8, see Daube (1956:312).

4 The only way out is the assumption of a different chronology. Jesus was neither before nor after the feast arrested and executed according to Mark 14:2-3. For the difficilty of interpreting Mark 14:1-3, see Bultmann (1931:282; cf also Ergänzungsheft 1958:38).

5 The body of those who try to get hold of Jesus is not mentioned, nor the problem of implementation indicated. The fear of the people replaces the fear of Jesus.

${ }^{6}$ The absence of $\dot{\varepsilon} \nu \delta o ́ \lambda \omega$ in D is lectio facilior.

7 They are not individual stories which are loosely strung together, not a Rankenwerk of Anekdoten, preserved more or less casually (thus Schmidt 1919). Schmidt (1919:104), however, also admits that the 'Wirksamkeit Jesu derartig konsequent unter bestimmten Kategorien betrachtet ist'. The opinion of Kuhn $(1971: 86,88)$, that Mark 3:1-5 was not added to the collection before the redaction does not recommend itself.

${ }^{8}$ It is the miracle which gives dignity and qualification to the message. Here it is placed at the beginning of a sequel which is meant to be representative for the whole ministry, while it is given its location after the sermon on the plain in $Q($ Lk 7:1).

${ }^{9}$ It is, however, likely that $\beta \lambda \alpha \sigma \phi \eta \mu \varepsilon \hat{\imath}$ is to be qualified by a question mark rather than a full stop with the meaning of an exclamation (Mk 1:27).

10 Mark 3:6 is not of a piece with the preceeding verses but not due to the redaction of the evangelist, as Bultmann (1966:157) assumes, because it is at variance with Mark's own view on the trial. It evinces an interim redaction of this set of stories.

11 Is Luke's claim that Herod himself had a hand in the trial of Jesus (Lk 23:6-12) a more or less distant reflection of the historical situation? For this problem see Hoehner (1972) and Bammel \& Moule (1984:423ff).

12 The alternative version of Mark 2:15f may indicate a like açtivity of the scribes of the Pharisees $(\gamma \rho \alpha \mu \mu \alpha \tau \varepsilon \hat{\imath} \varsigma \tau \hat{\omega} \nu \Phi \alpha \rho \iota \sigma \alpha i \omega \nu)$.

13 Luke adds colour to it. The Markan $\pi \alpha \rho \alpha \tau \eta \rho \varepsilon \omega$ is taken up in the Lukan passage 14:1 and

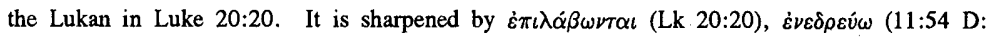

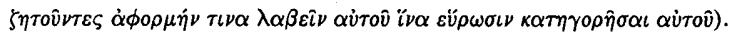


14 Although the frequency of the usage of the term in the story may have other reasons as well. Interesting is $\mathrm{D}$ in verse 56: the addition of $\kappa \alpha \grave{\imath} \dot{\varepsilon} \lambda \varepsilon \gamma o \nu$, together with $\kappa \alpha \tau^{\prime} \alpha \dot{v} \tau o \hat{v}$ describes the action, whereas $\dot{\varepsilon} \psi \varepsilon v \delta \delta \mu \alpha \rho \tau i \rho o v \nu$ is a characterization, which only in verse $56 \mathrm{~b}$ is followed by a judicial evaluation.

15 See note 25 .

16 Achan is questioned by Joshua (7:19). Having admitted his guilt he is stoned and burnt. הרמ had been taken away. His transgression had been found out by an ordeal according to Ant Bibl 25.7 , that means by divine intervention.

17 The case of Luke 19:22 is not one of criminal law.

18 For the very rare cases where one witness suffices, see Saalschütz (1953:604f). The testimony of one witness could laad to the exclusion from the Damascus community.

19 Keim (1872) is so keen to make the Matthean text comply with the regulation that he paraphrases it by '... ein zweiter oder gar ein dritter Zeuge'.

20 Dörr's (1920:31) assumption that this was the case is indicative for the uneasiness of an approach from the basis of Roman law.

21 A defence or rather a restatement of his message was given by Jeremiah, when accused by 'the priests, the prophets and the whole people'. The judicial situation is different from that of the later period: judgment is given by the 'princes' (Jr 26:16). The 'whole people' had been on the side of the priests and prophets at the hour of accusation (verse 8), whereas they are found with the princes when the judgment is pronounced (verse 16).

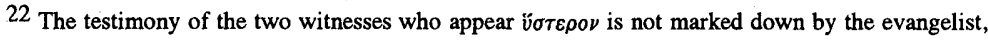
it is in his view valid. This means the question must have been put as a way to give support to the accused.

23 Mark 14:59 mentions the collapse of the accusation. The question is therefore designed to refloat the accusation.

24 'Within three days' may have belonged to the destruction phrase originally and been moved to the first part, when it was linked with Jesus's resurrection (Jn 2:21).

25 Even this is only narrated in the younger version. Whether the story was composed as a Rechtslegende (thus Brüll, Daube ect) or not (Engel 1985), it is certainly illustrative for the situation in the first century B C.

26 A Jew is expected to confess his sins at this stage (Sanh V1.2). Susannah's action is to be viewed against this background of recommended behaviour. 
27 Maximus, the gymnasiarch is accused during his trial of having kept silence (Act Mx, version A line $41 \mathrm{f}$ ). This detail is typical.

28 The possibility that trains of thought, descriptions and statements referring to one religion stimulated respective claims in another religion has to be taken seriously, especially in the case of rival religions. Daube (1956:5ff) took the view fifty years ago that Jewish claims on the early days of Moses were conceived as an answer to Luke 1f. The trial scene was certainly something that is inviting for the building up of rival claims and accounts. The story of Jesus ben Ananias, who is described by Josephus as having kept silence when confronted with the Jewish as well as the Roman authorities (Bell VI $\S 301 \mathrm{ff}$ ), is likely to have been coloured by the accounts of Jesus of Nazareth.

${ }^{29}$ His fellow prophets know that he is commissioned to utter a prophecy.

30 False witnesses (as opposed to witnesses whose testimonies disagreed with each other) were under certain circumstances liable to the death penalty. Christian sources never claim that the witnesses in this trial ought to have been punished in this way (for the rabbinic discussion, see Finkelstein 1962:696ff). Therefore, $\psi \varepsilon v \delta o \mu \alpha \rho \tau v \rho i \alpha$ is not used in the technical sense of the word but as a way to characterize the whole setting.

31 In rabbinic texts it is the word 'or' which is used in order to link traditions which have little or nothing to do with each other.

32 This is the consequence of Wellhausen's theory on the trial.

33 For an interpretation of the phrase which dispenses with a formal meaning, see Schalit (1963:91; cf Cohn 1972).

34 See note 33 .

35 Loss of juridical insight and its replacement by theological reflections - this development was explored by Stauffer in more than one publication.

36 Even the traditions preserved by Mark presuppose a longer stay by Jesus in Jerusalem: 'Er muss ... geraume Zeit vor dem Fest dort eingetroffen sein' (Wellhausen 1909:88).

\section{Works consulted}

Bakhuizen van den Brink, J N 1927. Eine Paradosis zu der Leidensgeschichte. ZNW 26, 213-219.

Baldensperger, W 1881. Das Selbstbewußtein Jesu. Strassburg: Publisher Heitz.

Bammel, E \& Moule, C F D 1984. Jesus and the politics of his day. Cambridge: Cambridge University Press.

Bertram, G 1922. Die Leidensgeschichte Jesu und der Chriuskult. Göttingen: Vandenhoeck. 
Blinzler, J 1969. Der Prozess Jesu. Regensburg: Pustet.

Brown, R F 1994. The death of the Messiah, I/II. London.

Bultmann, R [1921] 1931. Die Geschichte der synoptischen Tradition. Göttingen: Vandenhoeck.

- [1964] 1941. Das Evangelium des Johannes. Göttingen: Vandenhoeck.

Cohn, H 1972. The trial and death of Jesus. London.

Daube, D 1956. New Testament and rabbinic Judaism. London: Athlone Press.

Dibelius, M 1933. Die Formgeschichte des Evangeliums. Tübingen: Mohr.

Doerr, F 1920. Der Prozess Jesu in rechtsgeschichtlicher Beleuchtung. Berlin: Kohlhammer.

Engel, H 1985. Die Susanna-Erzählung. Göttingen: Vandenhoeck.

Finkelstein, L 1962. The Pharisees. Philadelphia: The Jewish Publication Society of America.

Hirsch, E [1940] 1941. Frühgeschichte des Evangeliums, I. Tübingen: Mohr.

Hoehner, H 1972. Herod Antipas. Cambridge: Cambridge University Press.

Innes, A T 1899. The trial of Jesus Christ: A legal monograph. Edinburgh: $\mathrm{T}$ and $\mathrm{T}$ Clark.

Keim, Th 1867-72. Jesus von Nazarah. Zürich: Orell, Füssli und Company.

Kilpatrick, G D 1953. The trial of Jesus. London: Friends of Dr Williams Library.

Knox, W 1953. The sources of the Synoptic Gospels, I. Cambridge: Cambridge University Press.

Kuhn, H W 1971. Ältere Sammlungen im Markusevangelium. Göttingen: Vandenhoeck.

Lieberman, S 1944/5. Roman legal institution in early Rabbinics and in the Acta Martyrum. JQR 35, 30-1-57.

Lietzmann, H 1931a. Der Prozess Jesu. SBA 14, 313.

— 1931b. Bemerkungen zum Prozeß, I. Jesu $Z N W 30,211-215$.

- 1932. Bemerkungen zum Prozeß, II. Jesu $Z N W 31,78-84$

- 1958. Kleine Schriften, II. Berlin: Akademie Verlag.

Lohmeyer, E 1937. Das Evangelium des Markus. Göttingen: Vandenhoeck.

Lührmann, D 1987. Das Markusevangelium. Tübingen: Mohr.

Mendelsoln, S 1968. The criminal jurisprudence of the ancient Hebrews. New York. Merx, A 1902. Matthaeus. Berlin: Reimer.

Paulus, C 1985. ZSav. Stiftg. Rom. Abtlg. Einige Bermerkungen zum Prozeß Jesu bei den Synoptikern.

Pesch, R 1977. Das Markusevangelium, II. Freiburg: Herder. 
Reiser, M 1984. Syntax und Stil des Markusevangeliums. Tübingen: Mohr. Saalschütz, I L 1853. 'Das mosaische Recht. Berlin.

Schalit, A 1963. Kritische Randbemerkungen zu Paul Winters 'On the trial of Jesus', Annual of the Swedish Theological Institute 2, 86-102.

Schmidt, K L 1919. Der Rahmen der Geschichte Jesu. Berlin: Trowitsch.

Schubert, P 1966. Die Erklärung des zweiten Vatikanischen Konzils über die Juden. Bibel und Liturgie 39, 16-25.

Schweizer, E 1967. Das Evangelium nach Markus. Göttingen: Vandenhoeck.

Stählin, G 1970. Festschrift. Wuppertal: Brockhaus.

Stauffer, E 1959. Festschrift O Eissfeld. Berlin: Akademieverlag. 19XX. Jesus, Geschichte und Verkündigung. ANRW 25 1, 3-130.

Thiel, R 1938. Drei Markusevangelien. Berlin: De Gruyter.

Trocmé, E 1983. The Passion as liturgy. London: SCM-Press.

Weiss, J 1903. Das Alteste Evangelium. Göttingen: Vandenhoeck.

Wellhausen, Ä 1909. Das Evangelium Marci. Berlin: Reimer. 1904. Das Evangelium Lucae. Berlin:Reimer.

Winter, P 1961. On the trial of Jesus. Berlin: De Guyter. 